\title{
Lastenkulttuurin kauhujen kartta
}

\section{Ylönen, Susanne 2016. Tappeleva rapuhirviö. Kauhun estetiikka lastenkulttuurissa. Jyväskylä Studies in Humanities 282. Jyväskylä: Jyväskylän yliopisto. 255 S.}

Millaisia kauhuja lapsille sallitaan ja millaisilta kauhuilta heitä varjellaan nykySuomessa? Susanne Ylösen taidekasvatuksen väitöskirja Tappeleva rapuhirviö. Kauhun estetiikka lastenkulttuurissa tarkastelee, miten kauhua merkityksellistetään alle kouluikäisille lapsille suunnatuissa kuvakirjoissa ja niitä ympäröivässä puheessa 2000-luvulla. Tutkimuksessa huomio on myös laajemmin lastenkulttuurin kauhua käsittelevissä diskursseissa ja niihin liittyvissä esteettisissä lähestymistavoissa.

Ylönen lähestyy kauhun käsitettä laajasti: taidefilosofi Noël Carrollia mukaillen hän määrittelee kauhun pelon ja inhon tunteita yhdisteleväksi affektiiviseksi ilmiöksi, joka välittyy kulttuurituotteiden kautta. Määritelmää tarkennetaan rajaamalla "kulttuurinen" eli tarinallistettu kauhu tyylitellyissä tarinoissa ja taiteessa esiintyvään sisältöön. Ylösen mukaan tutkimusta rajaa lisäksi aineisto, joka koostuu kolmesta 2000-luvulla julkaistusta suomalaisesta kuvakirjasta - Suna Vuoren ja Katri Kirkkopellon Hirveää, parkaisi hirviö (2005), Hannele Huovin ja Jukka Lemmetyn Miinalan Veikon nyrkkeilykoulu (2008) ja Aino \& Ville Tietäväisen Vain pahaa unta (2013) - ja päiväkotiopettajien, päiväkotilasten sekä Huovin ja Lemmetyn haastatteluista. Toisaalta voi ajatella, että monimuotoinen aineisto ei positiivisessa mielessä rajaa liikaa tutkimusta, jonka tavoitteena on lastenkulttuurin kauhun estetiikan teoretisointi. Kokonaisuutena tutkimusote on kulttuurintutkimuksellinen ja osin lapsilähtöinen: teoksen ympärillä olevista äänistä pääsevät kuuluviin myös lasten omat. Fokus on kuitenkin aikuisten luomissa kulttuurituotteissa ja aikuisten tuottamassa puheessa kauhusta. Ylönen tarkasteleekin lastenkulttuuria kriittisesti aikuisten vallankäytön välineenä.

Teoreettis-menetelmällisesti tutkimus nojaa fenomenologiseen ja diskurssianalyyttiseen lähestymistapaan, semioottiseen lähilukuun ja käsitteelliseen mallintamiseen. Kombinaatio sinänsä ei ole tuore. Tuttu ja testattu viitekehys mahdollistaa kuitenkin sellaisen uuden luomisen, joka on helposti muidenkin sovellettavissa - tässä kauhun estetiikan topografian. Topografia kuvataan esteettis-diskursiiviseksi kehikoksi, joka tarjoaa kolme lähestymistapaa kauhuun: esteettinen ylevöittäminen, estetisointi ja esteettinen härmistäminen. Karkeasti nämä ovat liitettävissä estetiikan tuttuihin käsitteisiin ylevä, kaunis ja groteski tai Ylösen kansantajuisiin termeihiin nostattaminen, kaunistaminen ja alentaminen. Lähestymistavat ovat Ylöselle tilallisia kokemuksia. 
Ylevöittäminen etäännyttää, estetisointi pinnallistaa ja härmistäminen tuo kauhun ihon alle. Puhe toiminnasta luokittelevien kategorioiden sijaan on harkittua. Ylönen tarkastelee, miten eri esteettiset lähestymistavat vaikuttavat siihen, kuinka kauhu merkityksellistetään ja arvotetaan. Ylönen soveltaa topografiaa paitsi lastenkirjoihin, myös tutkimuksen diskursiiviseen kontekstiin eli lasten kauhukulttuuria kehystäviin ja läpäiseviin diskursseihin, joiden arvottaviin elementteihin päästään mainiolla tapaa käsiksi esteettisten kategorioiden kautta. Tässä mielessä, etenkin kriittisen diskurssintutkijan näkökulmasta, myös kontekstualisoivat lähteet toimivat tutkimuksen kokonaisaineistona.

Ylönen erittelee neljä estetisoivaa diskurssia kauhusta lastenkulttuurissa: huolipuhe, psykologisointi, söpöily ja vertaiskulttuurinen merkityksellistäminen. Diskurssit nousevat sekä aiemmasta tutkimuksesta että Ylösen aineistoista. Huolipuhe on diskursseista kenties vakiintunein ja tutkituin. Estetiikaltaan se on ylevöittävää, lähestyy kauhua ulkopuolelta ja korostaa kauhun hallitsemattomia, haitallisia vaikutuksia lapsiyksilön psyykelle. Ylösen aineistoissa huolipuhe korostuu päiväkotiopettajien haastatteluissa, joissa se koskee paitsi lastenkulttuurituotteita myös lasten omia leikkejä. Psykologisointi diskurssina on myös ylevöittävää, ja osin asettuu huolipuheen kanssa limittäin, osin sitä vastaan: psykologisoinnin kautta kauhu voidaan paitsi patologisoida, myös nähdä terapeuttisena ja kasvattavana. Lastenkirjassa psykologisointi ja esteettinen ylevöittäminen voivat olla tapoja käsitellä kauhua sitä laimentamatta, mutta jollain tapaa selittäen, mistä tutkimuksessa esimerkkinä on lapsen painajaisten dramaattinen, mutta samalla terapeuttinen käsittely Tietäväisten kuvakirjassa. Haastatteluissa pohdintaan ja keskusteluihin kannustava psykologisointi korostui lastenkirjan tekijöiden puheessa, ja tekijät puhuivat lastenkirjallisuudesta rajoja rikkovana taiteena. Söpöily puolestaan on estetisoiva, pinnallistava tai "lapsellistava" diskurssi, joka pehmentää kauhut hauskoiksi, viattomiksi tai domestikoiduiksi ilmiöiksi. Diskurssi valottaa lastenkulttuurituotteita, joissa mikään ei oikeasti ole kauheaa, vaikka sisällöllisesti voidaan käsitellä hirviöitä tai kuolemaa, kuten Vuoren ja Kirkkopellon teoksessa.

Osittain näitä kaikkia ja etenkin huolipuhetta vastaan asettuu ala- ja fanikulttuureissa tyypillinen vertaiskulttuurinen diskurssi, joka antaa kauhulle positiivisia merkityksiä kauhukulttuurin harrastajien piiristä käsin. Tämä voi toteutua joko estetisointina, jossa kauhua lähestytään analyyttisesti tiedon ja tiedostavan kuluttamisen kautta tai esteettisenä härmistämisenä, joka näyttäytyy "roskan" arvostamisena. Roska on tietysti suhteellista - lastenkirjan kontekstissa roskana voivat joidenkin lukijoiden silmissä näyttäytyä poikkeukselliset tyylilliset ja sisällölliset keinot, kuten mustavalkoiset värit ja väkivallan vauhdikas sisällöllinen käsittely groteskia liioittelua hyödyntävässä Huovin ja Lemmetyn kuvakirjassa. Vertaiskulttuurinen diskurssi korostui haastateltavien lasten puheessa, jossa järkeistävän estetisoinnin ja humoristisen härmistämisen lisäksi kauhuun suhtauduttiin kuitenkin myös ylevöittävästi kuvaamalla aidosti painajaismaisia olentoja ja heittäytymällä kauhukokemuksiin. Vaikkei Ylönen 
lähde systemaattisesti erittelemään diskurssien suhteita, tutkimuksesta käy ilmi, että ne järjestäytyvät institutionaalisesti eri tavoin ja niillä on erilaista valtaa: esimerkiksi huolipuhe kiinnittyy valtion elokuvatarkastamon valvontaan. Kokonaisuutena diskurssien hahmottelu antaa lukijalle moniulotteisen kuvan lastenkulttuurin kauhuja koskevasta puheesta ja kauhun estetiikan eri lähestymistavoista.

Ylösen tutkimus on hallittu ja taitavasti kirjoitettu kokonaisuus, jota lukiessaan välillä unohtaa käsissään olevan väitöskirjan. Teokseen perehtyminen ei edellytä rajatun erityisalan syvällistä ymmärtämistä eikä alkupaloiksi tuhdin lähdeviitteistön läpi pureskelua. Tappeleva rapuhirviö on ehdottomasti suositeltavaa luettavaa kaikille lastenkirjallisuudesta ja kulttuurista kiinnostuneille, mutta kirjan soisi tavoittavan suuremmankin yleisön. Kauhun estetiikan topografinen tarkastelu suhteessa arkiseen ja institutionaaliseen puheeseen kauhusta sekä tutkimusote, joka yhdistää semioottisen lähiluvun kulttuurituotteiden tuottajien ja käyttäjien haastatteluihin tarjoavat verevöittävää ajateltavaa ja terävät hampaat laajemminkin kauhua tarkastelevaan taiteen- ja kulttuurintutkimukseen.

Sanna Tapionkaski 